\title{
Amyloid $\beta$-Peptide Impairs Glucose Transport in Hippocampal and Cortical Neurons: Involvement of Membrane Lipid Peroxidation
}

\author{
Robert J. Mark, ${ }^{1}$ Zhen Pang, ${ }^{1}$ James W. Geddes, ${ }^{1}$ Koji Uchida, ${ }^{2}$ and Mark P. Mattson ${ }^{1}$ \\ 1 Sanders-Brown Research Center on Aging and Department of Anatomy and Neurobiology, University of Kentucky, \\ Lexington, Kentucky 40536, and 'Laboratory of Food and Biodynamics, Nagoya University, Nagoya, 464-01 Japan
}

\begin{abstract}
A deficit in glucose uptake and a deposition of amyloid $\beta$-peptide $(A \beta)$ each occur in vulnerable brain regions in Alzheimer's disease (AD). It is not known whether mechanistic links exist between $A \beta$ deposition and impaired glucose transport. We now report that $A \beta$ impairs glucose transport in cultured rat hippocampal and cortical neurons by a mechanism involving membrane lipid peroxidation. $A \beta$ impaired ${ }^{3} \mathrm{H}$-deoxy-glucose transport in a concentration-dependent manner and with a time course preceding neurodegeneration. The decrease in glucose transport was followed by a decrease in cellular ATP levels. Impairment of glucose transport, ATP depletion, and cell death were each prevented in cultures pretreated with antioxidants. Exposure to $\mathrm{FeSO}_{4}$, an established inducer of lipid peroxidation, also impaired glucose transport. Immunoprecipitation and Western blot analyses showed that exposure of cultures to $A \beta$
\end{abstract}

induced conjugation of 4-hydroxynonenal (HNE), an aldehydic product of lipid peroxidation, to the neuronal glucose transport protein GLUT3. HNE induced a concentration-dependent impairment of glucose transport and subsequent ATP depletion. Impaired glucose transport was not caused by a decreased energy demand in the neurons, because ouabain, which inhibits $\mathrm{Na}^{+} / \mathrm{K}^{+}$-ATPase activity and thereby reduces neuronal ATP hydrolysis rate, had little or no effect on glucose transport. Collectively, the data demonstrate that lipid peroxidation mediates $A \beta$-induced impairment of glucose transport in neurons and suggest that this action of $A \beta$ may contribute to decreased glucose uptake and neuronal degeneration in AD.

Key words: Alzheimer's disease; apoptosis; excitotoxicity; GLUT3; hydroxynonenal; mitochondrial ATP
Alzheimer's Disease (AD) is a progressive neurodegenerative disorder characterized by gradual impairment of memory function and accumulation of neurofibrillary tangles and neuritic plaques in brain regions subserving cognitive functions (for review, see Selkoe, 1993). A consistent feature of AD patients, detected by brain imaging methods, is impairment of glucose uptake in brain regions that exhibit neuritic plaques (Hoyer et al., 1988; Kalaria and Harik, 1989; Sims, 1990; Jagust et al., 1991). Studies of persons genetically at risk for AD suggest that reduced glucose uptake may occur early in the disease process before neuronal degeneration (Pettegrew et al., 1994; Kennedy et al., 1995; Reiman et al., 1996). Moreover, large decreases in the activities of two major mitochondrial enzyme systems, pyruvate dehydrogenase complex and ketoglutarate dehydrogenase complex, have been reported (for review, see Blass, 1993). When glucose uptake into neurons is compromised, mitocondrial production of ATP is suppressed, resulting in increased vulnerability to excitotoxic calcium overload (Novelli et al., 1988; Cheng and Mattson, 1992a,b), a mechanism of cell injury implicated in the pathogenesis of AD (for reviews, see Greenamyre and Young, 1989; Mattson et al., 1993a). Glucose uptake in the brain is mediated by specific transport proteins: GLUT1 in endothelial cells and GLUT3 in neurons (Simpson et al., 1994a). Recent data suggest that levels of these

Received Sept. 25, 1996; revised Nov. 12, 1996; accepted Nov. 14, 1996.

This work was supported by grants to M.P.M. from National Institutes of Health (NS30583 and AG10836), the Alzheimer's Association (Zenith Award), and the Metropolitan Life Foundation; to J.W.G. from National Institutes of Health (AG05144); and a National Institute on Aging training grant fellowship to R.J.M. We thank S. Bose, W. Fu, R. Pelphrey, and J. G. Begley for technical assistance.

Correspondence should be addressed to Mark P. Mattson, 211 Sanders-Brown Building, University of Kentucky, 800 South Limestone, Lexington, KY 40536-0230.

Copyright (C) 1997 Society for Neuroscience $0270-6474 / 97 / 171046-09 \$ 05.00 / 0$ transporters are decreased in AD brain (Simpson et al., 1994b; Harr et al., 1995).

The major component of neuritic plaques is amyloid $\beta$-peptide $(\mathrm{A} \beta)$, a 40-42 amino acid proteolytic fragment of the $\beta$-amyloid precursor protein ( $\beta$ APP) (Selkoe, 1993). Molecular genetic studies have causally linked $\beta$ APP mutations to some inherited forms of AD (for review, see Mullan and Crawford, 1993); the mutations may promote increased production of $\mathrm{A} \beta$ (Citron et al., 1992; Cai et al., 1993; Suzuki et al., 1994). Transgenic mice expressing a mutated form of human $\beta$ APP exhibit age-dependent and brain region-specific deposition of $\mathrm{A} \beta$ that is associated with neuronal degeneration (Games et al., 1995; Hsaio et al., 1996). A $\beta$, and an 11 amino acid fragment thereof (A $\beta 25-35)$, can be neurotoxic by a mechanism linked to peptide fibril formation (for review, see Yankner, 1996). The mechanism of $\mathrm{A} \beta$ toxicity may involve membrane lipid peroxidation (Behl et al., 1994; Butterfield et al., 1994), disruption of ion homeostasis (Mattson et al., 1992, 1993b), and apoptosis (Loo et al., 1993). Lipid peroxidation induced by $\mathrm{A} \beta$ has been linked to impairment of membrane transport and signaling systems, including ion-motive ATPases (Mark et al., 1995a), glutamate transporters (Harris et al., 1996; Keller et al., 1997), and the muscarinic cholinergic acetylcholine receptorGTP-binding protein system (Kelly et al., 1996).

Oxidative stress is prevalent in $\mathrm{AD}$ brain: levels of protein (Smith et al., 1991) and lipid (Lovell et al., 1995) oxidation are increased in vulnerable regions and advanced glycation end products are associated with neuritic plaques and neurofibrillary tangles (for review, see Smith et al., 1995). 4-Hydroxynonenal (HNE), an aldehydic product of lipid peroxidation, is neurotoxic (Montine et al., 1996; Mark et al., 1997) and can impair ion-motive ATPase activities and disrupt calcium homeostasis in cultured hippocam- 
pal neurons (Mark et al., 1997). We now report that $\mathrm{A} \beta$ impairs glucose uptake and depresses ATP levels in cultured rat hippocampal and cortical neurons, and provide evidence that this action of $\mathrm{A} \beta$ is mediated by membrane lipid peroxidation and conjugation of HNE to GLUT3.

\section{MATERIALS AND METHODS}

Cell culture, experimental treatments, and quantification of neuron survival. Primary hippocampal and cortical cell cultures were established from embryonic rats (day 18 of gestation), as detailed elsewhere (Mattson et al., 1995). Cells were plated into polyethyleneimine-coated plastic culture dishes at a density of $70-120 / \mathrm{mm}^{2}$. The cultures were maintained in Eagle's minimum essential medium supplemented with $10 \%(\mathrm{v} / \mathrm{v})$ heatinactivated fetal bovine serum (Life Technologies, Gaithersburg, MD), 20 $\mathrm{mm} \mathrm{KCl}$, and $1 \mathrm{~mm}$ pyruvate. The atmosphere consisted of $6 \% \mathrm{CO}_{2} / 94 \%$ room air and was maintained near saturation with water. Experiments were performed in cultures that had been maintained for $6-10 \mathrm{~d}$. With these culture conditions, $\sim 90 \%$ of the cells are neurons and the remaining cells are astrocytes, as judged by characteristic morphology and differential immunoreactivity with antibodies to neuron-specific (neurofilament, MAP2, and tau) and astrocyte-specific (glial fibrillary acidic protein and S-100 $\beta$ ) proteins (Mattson et al., 1993b, 1995). In some experiments, cultures were prepared that contained only neurons or only astrocytes. Pure neuronal cultures were prepared by maintaining the embryonic cell cultures in serum-free medium (Neurobasal, Life Technologies). Pure astrocyte cultures were prepared by plating cells from postnatal rat cerebral cortex in uncoated plastic culture dishes and changing the serum-containing medium daily.

Immediately before experimental treatment, the culture maintenance medium was replaced with Locke's solution containing (in mM): $154 \mathrm{NaCl}$, $5.6 \mathrm{KCl}, 2.3 \mathrm{CaCl}_{2}, 1.0 \mathrm{MgCl}_{2}, 3.6 \mathrm{NaHCO}_{3}, 10$ glucose, 5 HEPES buffer, pH 7.2. A $\beta 25-35$ (lot ZM513) and A $\beta 1-40$ (lot ZK600) were purchased from Bachem. Peptides were stored lyophilized, and $1 \mathrm{~mm}$ stocks (in water) were prepared 2-4 hr before use. HNE was purchased from Caymen Chemical (Ann Arbor, MI). Ouabain, $n$-propyl gallate, phloretin, and protein A-acrylic beads were purchased from Sigma (St. Louis, MO). Neuron survival was quantified by counting the number of viable neurons in premarked microscope fields before and at indicated time points after exposure to experimental treatments, as described previously (Mattson et al., 1992, 1995).

Glucose transport assay. Uptake of $\left[{ }^{3} \mathrm{H}\right]$-glucose was performed using a variation of the method of Horner et al. (1990). Before the addition of experimental treatments, the cultures were switched to Locke's solution. After treatments and just before the uptake assay, cultures were switched to glucose-free Locke's solution by first washing them three times with glucose-free Locke's. The assay was started by the addition of $1.5 \mu \mathrm{Ci}$ of $\left[{ }^{3} \mathrm{H}\right]-2$-deoxy-glucose (New England Nuclear), and cultures were maintained at $37^{\circ} \mathrm{C}$. The assay was stopped 5 min later by aspiration of the supernatant and rapid washing with PBS (three rinses, 5-7 sec/rinse). Cells were lysed in $200 \mu \mathrm{l}$ of a $0.5 \mathrm{~N} \mathrm{NaOH} / 0.05 \%$ SDS solution; $10 \mu \mathrm{l}$ was used for protein determination (Pierce BCA kit; Pierce, Rockford, IL), and the remainder was counted in a Packard 2500TR liquid scintillation counter. Data are expressed as cpm $\left[{ }^{3} \mathrm{H}\right]-2$-deoxy-glucose per milligram protein per minute.

Immunoprecipitation and Western blot analysis. Immunoprecipitations were performed as described (Barger and Mattson, 1996). Briefly, after treatment cultures were lysed in RIPA buffer $(50 \mathrm{~mm}$ Tris- $\mathrm{HCl}, 10 \%$ glycerol, $1 \%$ Triton X-100, $150 \mathrm{~mm} \mathrm{NaCl}, 100 \mathrm{~mm} \mathrm{NaF}, 5 \mathrm{~mm}$ EDTA, 2 mM phenylmethylsulfonyl fluoride, $1 \mathrm{~mm}$ sodium orthovanadate, and 1 $\mu \mathrm{g} / \mathrm{ml}$ leupeptin, $\mathrm{pH} 7.5$ ). GLUT3 protein was immunoprecipitated from $400 \mu \mathrm{g}$ of total cellular protein using a polyclonal antibody directed against a C-terminus peptide of GLUT3 (Chemicon, Temecula, CA). The antibody-lysate solution was left overnight at $4{ }^{\circ} \mathrm{C}$ on a rotary shaker, and the antibody-antigen complex was then pelleted using protein A linked to acrylic beads. The pellet was washed three times with ice-cold RIPA buffer, and the final pellet was suspended in $2 \times$ Laemmli sample buffer. Samples were boiled for $3 \mathrm{~min}$ and centrifuged at $3000 \mathrm{rpm}$ for $30 \mathrm{sec}$, and the supernatant was loaded on a 7.5\% SDS-PAGE gel. Protein was transferred to nitrocellulose, and the blot was incubated with a rabbit polyclonal antibody generated against HNE-protein conjugates (Uchida et al., 1993). The blot was processed further using HRP-conjugated secondary antibody and a chemiluminescence detection method (Amersham, Arlington Heights, IL).

Immunocytochemistry. Cells were fixed for $30 \mathrm{~min}$ in PBS containing
$4 \%$ paraformaldehyde $\left(4^{\circ} \mathrm{C}\right)$. Membranes were permeabilized by exposing the fixed cells to PBS containing $0.2 \%$ Triton X-100. Cells were then incubated sequentially in PBS solutions containing blocking serum $(1 \%$ normal goat serum), primary anti-GLUT3 antibody (1:500; $4 \mathrm{hr}$ ), biotinylated anti-rabbit secondary antibody (Vector Labs, Burlingame, CA; 1 $\mathrm{hr}$ ), avidin-peroxidase complex (Vector Labs; $30 \mathrm{~min}$ ), and diaminobenzidine-tetrahydrochloride (Sigma; $5 \mathrm{~min}$ ).

Quantification of cellular ATP levels. ATP levels were quantified using a luciferin/luciferase-based assay. Cells were exposed to experimental treatments in Locke's solution. To begin the assay, cells were rinsed with PBS and lysed with $0.2 \mathrm{ml}$ of ATP-releasing buffer (Sigma); $10 \mu \mathrm{l}$ of the lysate was taken for protein determination. ATP concentrations in lysates were quantified using an ATP Bioluminescence Assay Kit CH II (Boehringer Mannheim, Mannheim, Germany) and a luminometer (Optocomp I, MGM Instruments) according to the manufacturers' protocols. A standard curve was generated using solutions of known ATP concentrations; samples were diluted so that readings fell within the linear range. ATP levels were expressed as nanomole ATP per microgram protein.

\section{RESULTS}

\section{$A \beta$ impairs glucose transport in hippocampal and cortical neurons}

Preliminary studies showed that, as expected from previous studies (Horner et al., 1990), $>90 \%$ of the $\left[{ }^{3} \mathrm{H}\right]$-glucose uptake in both hippocampal and cortical cells was blocked by phloretin, indicating mediation by a specific glucose transporter. Levels of $\left[{ }^{3} \mathrm{H}\right]$ glucose uptake were $\left(\mathrm{cpm} \cdot \mathrm{mg}^{-1} \cdot \mathrm{min}^{-1}\right)$ : untreated control hippocampal cultures, 35,400 \pm 580 ; hippocampal cultures exposed to $100 \mu \mathrm{M}$ phloretin, $1908 \pm 144$; control cortical cultures, $16,500 \pm 1300$; cortical cultures exposed to $100 \mu \mathrm{M}$ phloretin, $1372 \pm 179 ; n=6$. The basal rate of glucose uptake in hippocampal cells was greater than twofold the rate of uptake in cortical cells ( $p<0.001$; paired $t$ test; Fig. $1 A$ ). Exposure of cultures to increasing concentrations of $\mathrm{A} \beta 25-35$ for $2 \mathrm{hr}$ resulted in concentration-dependent decreases in the rate of uptake of $\left[{ }^{3} \mathrm{H}\right]$ deoxy-glucose in both hippocampal and cortical cells (Fig. 1 $A$ ). The minimum concentration of $\mathrm{A} \beta 25-35$ required to induce a significant decrease in glucose transport was $5 \mu \mathrm{M}$ in hippocampal cells and $10 \mu \mathrm{M}$ in cortical cells. The extent of inhibition of glucose transport in cultures exposed to $50 \mu \mathrm{M} \mathrm{A} \beta 25-35$ was $\sim 65 \%$ in hippocampal cells and $50 \%$ in cortical cells. The time courses of impairment of glucose transport in hippocampal and cortical cultures exposed to $10 \mu \mathrm{M} \mathrm{A} \beta 25-35$ were similar, with the first significant decrease occurring within $2 \mathrm{hr}$ of exposure and a further decline to $\sim 50 \%$ inhibition by $3 \mathrm{hr}$ (Fig. $1 B$ ). Between 4 and $10 \mathrm{hr}$ of exposure to $\mathrm{A} \beta 25-35$, the rate of decrease in glucose transport slowed considerably. Impairment of glucose transport in cultures exposed to $\mathrm{A} \beta 25-35$ preceded cell degeneration; there was no significant cell loss during a $6 \mathrm{hr}$ exposure to $10 \mu \mathrm{M}$ A $\beta 25-35$, and $\sim 20 \%$ reduction in survival during a $12 \mathrm{hr}$ exposure (Fig. $1 C$ ). Previous studies have shown that $A \beta 25-35$ and $A \beta 1-40$ exhibit similar neurotoxic profiles with similar, if not identical, mechanisms of action (Yankner et al., 1990; Mattson et al., 1992; Pike et al., 1993; Mark et al., 1995a). In the present study we found that, as expected, A $\beta 1-40$ also significantly decreased glucose uptake in a concentration-dependent manner during a $6 \mathrm{hr}$ exposure period (Fig. 1D). Exposure of hippocampal cultures to $50 \mu \mathrm{M}$ of inactive (nontoxic) "overaged" $\mathrm{A} \beta 25-35$ (Mattson, 1995) for time periods of up to $10 \mathrm{hr}$ had no significant effect on glucose transport (data not shown), further suggesting a link between impairment of glucose transport and neurotoxicity of the peptide.

\section{Evidence that oxidative stress mediates $A \beta$-induced inhibition of glucose transport}

Previous studies showed that $\mathrm{A} \beta$ can induce membrane lipid peroxidation in cultured neurons and that antioxidants can pro- 

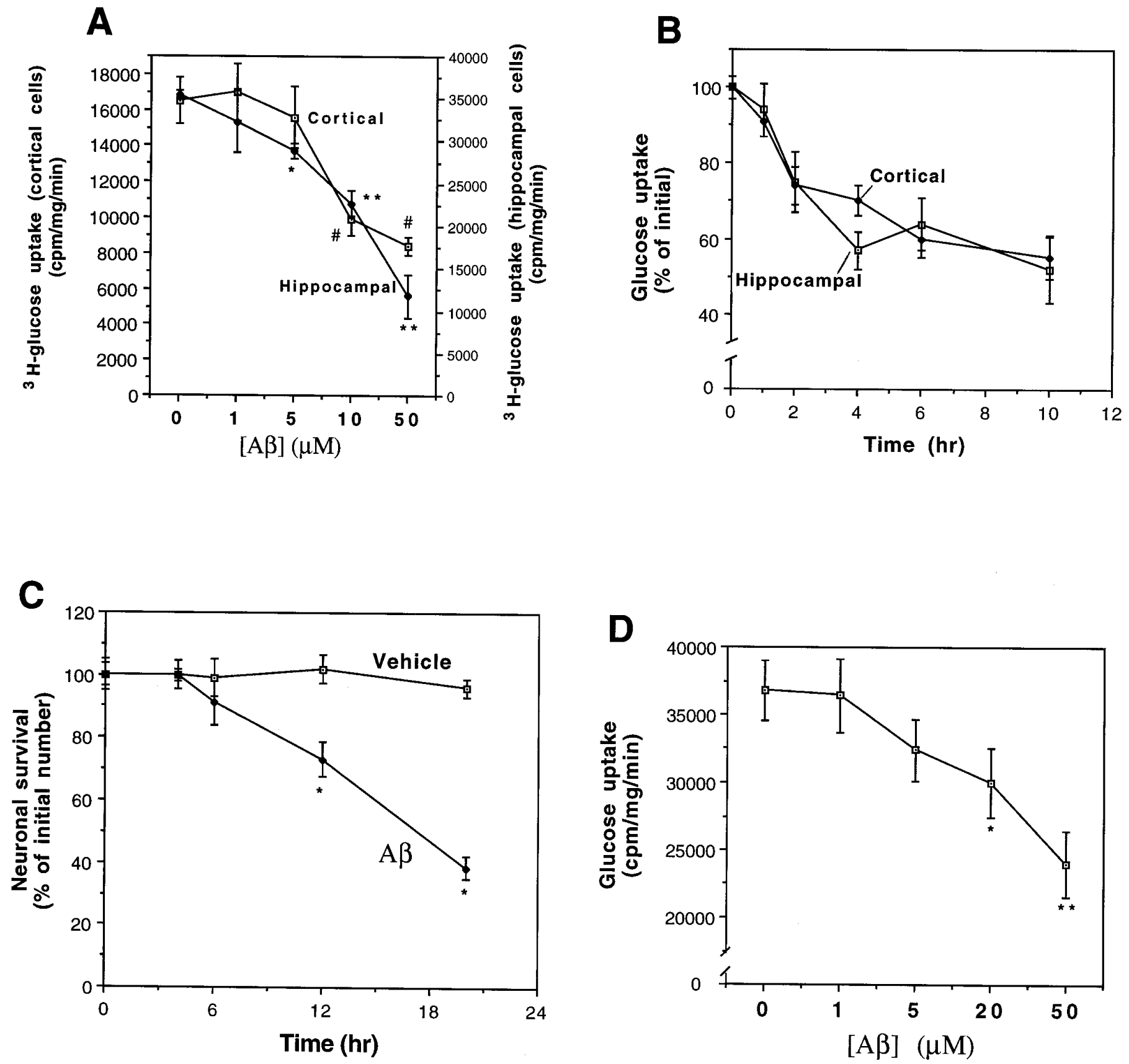

Figure 1. $\mathrm{A} \beta$ induces a concentration-dependent decrease in glucose uptake in hippocampal and cortical cell cultures with a time course that precedes cell death. $A$, Neocortical and hippocampal cell cultures were exposed for $2 \mathrm{hr}$ to vehicle or the indicated concentrations of $\mathrm{A} \beta 25-35$, and cellular uptake of $\left[{ }^{3} \mathrm{H}\right]$-glucose uptake was quantified. Values are the mean and SD of determinations made in six separate cultures. ${ }^{*} p<0.01$, ${ }^{* *} p<0.001$ for hippocampal cultures; $\# p<0.01$ for cortical cultures, compared to cultures exposed to vehicle $(0[\mathrm{~A} \beta])$. $B$, Cortical and hippocampal cultures were exposed to $10 \mu \mathrm{M} \mathrm{A} \beta 25$-35 for the indicated time periods, and $\left[{ }^{3} \mathrm{H}\right]$-glucose uptake was quantified. Values represent the mean and SD of determinations made in four to seven separate cultures. The decrease in glucose uptake was significant for both cortical and hippocampal cultures at the $2 \mathrm{hr}(p<0.05)$, and 4,6 , and $10 \mathrm{hr}(p<0.01)$ time points. ANOVA with Scheffe's post hoc tests. $C$, Hippocampal cultures were exposed to vehicle or $10 \mu \mathrm{M}$ A $\beta 25-35$ for the indicated time periods, and neuronal survival was quantified (see Materials and Methods). Values represent the mean and SD of five separate cultures. ${ }^{*} p<0.005$ (ANOVA with Scheffe's post hoc test). D. Hippocampal cultures were exposed for $6 \mathrm{hr}$ to A $\beta 1-40$ at the indicated concentrations, and $\left[{ }^{3} \mathrm{H}\right]$-glucose uptake was quantified. Values represent the mean and SD of determinations made in four separate cultures. ${ }^{*} p<0.05$, ${ }^{* *} p<0.001$ compared to control $(0 \mathrm{~A} \beta)$ value. ANOVA with Scheffe's post hoc analysis.

tect neurons against $\mathrm{A} \beta$ toxicity (Behl et al., 1994; Butterfield et al., 1994; Goodman and Mattson, 1994; Goodman et al., 1996) and $\mathrm{A} \beta$-induced impairment of ion-motive ATPase activity (Mark et al., 1995a). When hippocampal and cortical cultures were exposed to $50 \mu \mathrm{M} \mathrm{FeSO}_{4}(2 \mathrm{hr})$, an agent that induces hydroxyl radical production and lipid peroxidation (Zhang et al., 1993; Goodman et al., 1996), a highly significant 50-60\% decrease in glucose transport occurred (Fig. 2). Pretreatment of cultures with $10 \mu \mathrm{M}$ of the antioxidant $n$-propyl gallate or $50 \mu \mathrm{g} / \mathrm{ml}$ vitamin $\mathrm{E}$ resulted in complete prevention of $\mathrm{A} \beta 25$-35-induced impairment 


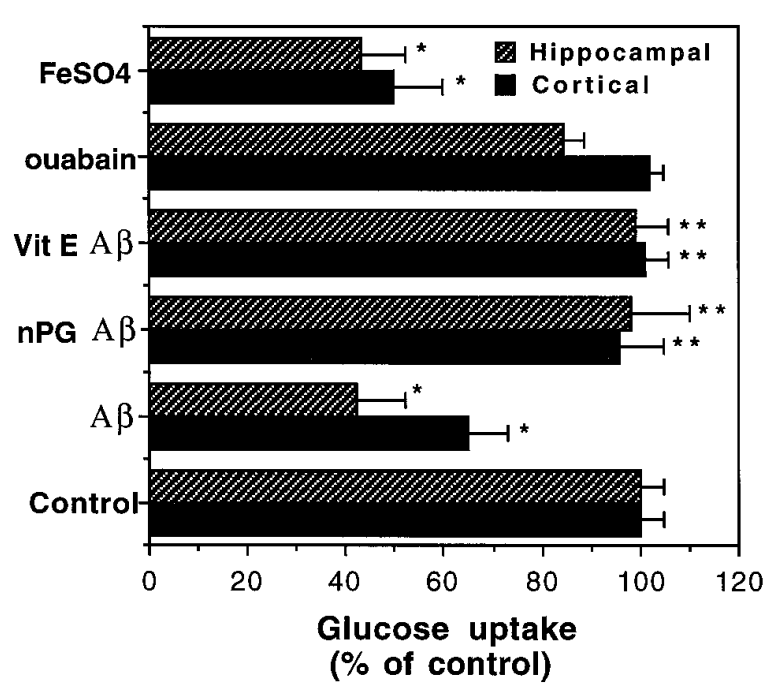

Figure 2. Evidence for the involvement of reactive oxygen species in $\mathrm{A} \beta$-induced impairment of glucose uptake. Hippocampal and cortical cultures were pretreated for $16 \mathrm{hr}$ with vehicle or $50 \mu \mathrm{g} / \mathrm{ml}$ vitamin $\mathrm{E}$ (Vit E), or for $2 \mathrm{hr}$ with $10 \mu \mathrm{M} n$-propyl gallate $(n P G)$. Cultures were then exposed for $2 \mathrm{hr}$ to water (Control), $50 \mu \mathrm{M} \mathrm{A} \beta 25-35,10 \mu \mathrm{M}$ ouabain, or $50 \mu \mathrm{M} \mathrm{FeSO}$. The levels of $\left[{ }^{3} \mathrm{H}\right]$-glucose uptake were quantified, and values (expressed as percentage of control) represent the mean and SD of determinations made in at least eight separate cultures. ${ }^{*} p<0.01$ compared to control cultures; ${ }^{* *} p<0.001$ compared to A $\beta$-treated cultures. ANOVA with Scheffe's post hoc analysis.

of glucose transport (Fig. 2), indicating the involvement of free radicals in this action of $A \beta 25-35$. Because $A \beta$ can impair $\mathrm{Na}^{+} /$ $\mathrm{K}^{+}$-ATPase activity (Mark et al., 1995a), the major utilizer of cellular ATP (Sweadner, 1989), it was conceivable that reduced glucose transport after exposure to $\mathrm{A} \beta$ resulted from a reduced demand of the cells for ATP. We therefore examined the effects of ouabain, a specific inhibitor of the $\mathrm{Na}^{+} / \mathrm{K}^{+}$-ATPase, on glucose transport rate. We exposed cultures to a concentration of ouabain $(10 \mu \mathrm{M})$ that resulted, as we showed previously, in a $50 \%$ reduction in $\mathrm{Na}^{+} / \mathrm{K}^{+}$-ATPase activity in hippocampal cell cultures, a level of inhibition equivalent to that induced by $10 \mu \mathrm{M} \mathrm{A} \beta 25-35$ (Mark et al., 1995a). A 2 hr exposure to ouabain had no significant effect on glucose transport in either hippocampal or cortical cells (Fig. 2).

\section{A $\boldsymbol{\beta}$ decreases cellular ATP levels}

To determine whether the level of impairment of glucose transport induced by $\mathrm{A} \beta$ was sufficient to cause a decrease in intracellular ATP levels, we quantified ATP levels in cultured cortical cells at different time points after exposure to $10 \mu \mathrm{M} \mathrm{A} \beta 25-35$. A $\beta 25-35$ induced a time-dependent decrease in ATP levels, with the first significant $(20 \%)$ decrease occurring at the $4 \mathrm{hr}$ time point (Fig. $3 A$ ). ATP levels thereafter declined at a very slow rate through $10 \mathrm{hr}$ of exposure to $\mathrm{A} \beta 25-35$, with levels being reduced by $25-30 \%$ at that time point. Thus, impairment of glucose transport (Fig. $1 B$ ) precedes depletion of cellular ATP. If A $\beta$-induced impairment of glucose transport is mechanistically relevant to $\mathrm{A} \beta$-induced neurotoxicity, then partial inhibition of glucose uptake by phloretin should cause toxicity. Phloretin induced a concentration-dependent neurotoxicity in hippocampal cell cultures (Fig. 3B).
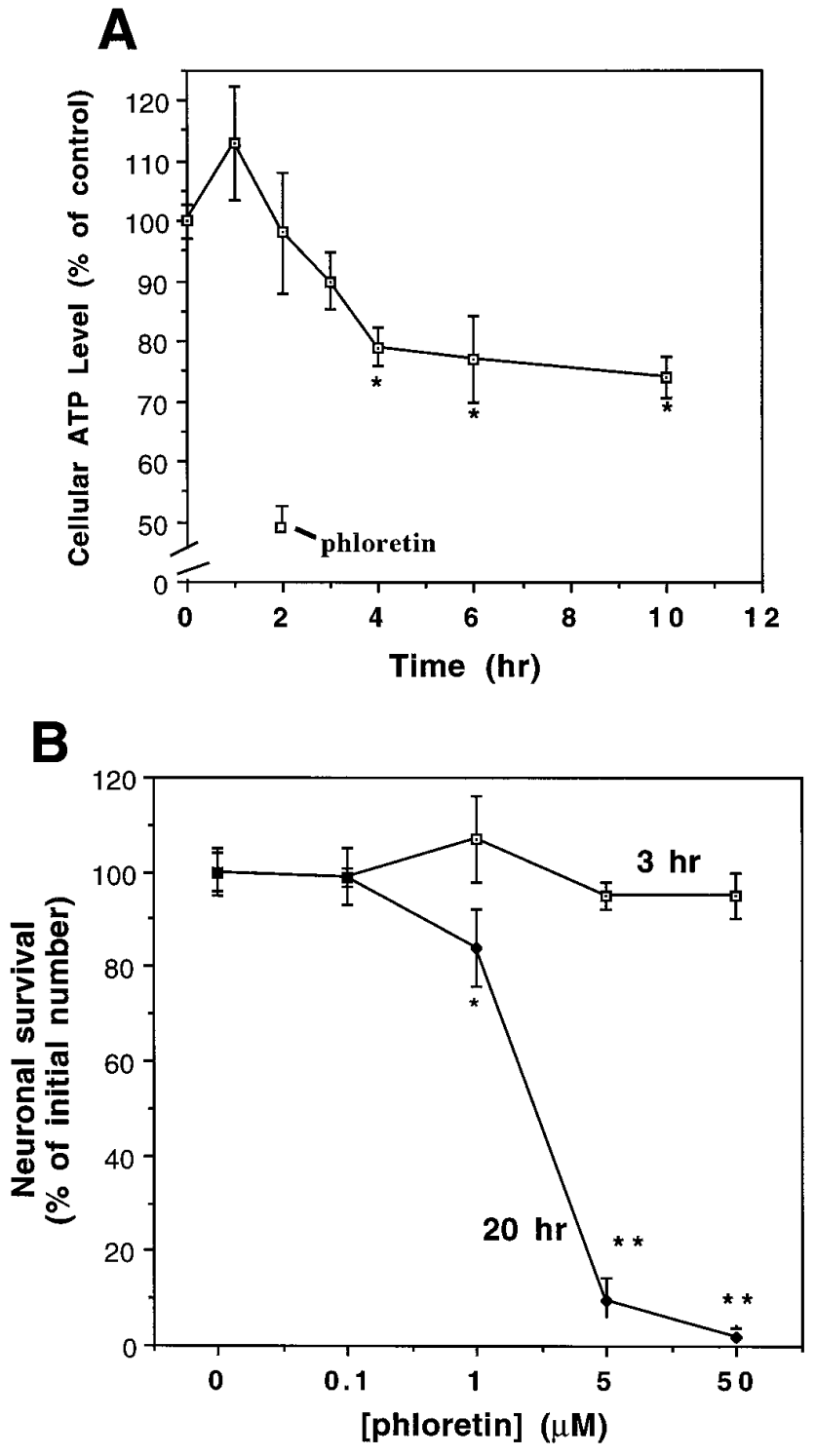

Figure 3. $A, \mathrm{~A} \beta$ induces a decrease in cellular ATP levels with a time course that follows impairment of glucose uptake. Neocortical cultures were exposed to $10 \mu \mathrm{M} \mathrm{A} \beta 25-35$ for the indicated time periods and intracellular ATP levels were quantified (see Materials and Methods). Additional cultures were exposed to $5 \mu \mathrm{M}$ phloretin for $2 \mathrm{hr}$. Values are expressed as percentage of the value in untreated control cultures and represent the mean and SD of determinations made in 5-15 separate cultures. * $p<0.05$ compared to control cultures; ANOVA with Fischer's post hoc analysis. The level of ATP in untreated control cultures was $29.2 \pm 0.98 \mathrm{nmol} \mathrm{ATP} / \mathrm{mg}$ protein. $B$, Phloretin induces a time- and concentration-dependent decrease in neuronal survival. Hippocampal cultures were exposed to the indicated concentrations of phloretin, and neuronal survival was determined 3 and $20 \mathrm{hr}$ later. Values represent the mean and SD from five separate cultures. ${ }^{*} p<0.01,{ }^{*} p<0.001$ as compared to control cultures. ANOVA with Scheffe's post hoc analysis.

\section{Involvement of the lipid peroxidation product HNE in A $\beta$-induced impairment of glucose transport}

We reported previously that $\mathrm{A} \beta$ induces the production of $\mathrm{HNE}$, a cytotoxic product of lipid peroxidation (Esterbauer et al., 1991), in cultured rat hippocampal neurons (Mark et al., 1997). In the latter study we also showed that HNE impairs $\mathrm{Na}^{+} / \mathrm{K}^{+}$-ATPase activity and is neurotoxic. To determine whether HNE plays a role in impairment of glucose transport induced by $\mathrm{A} \beta$, we determined 

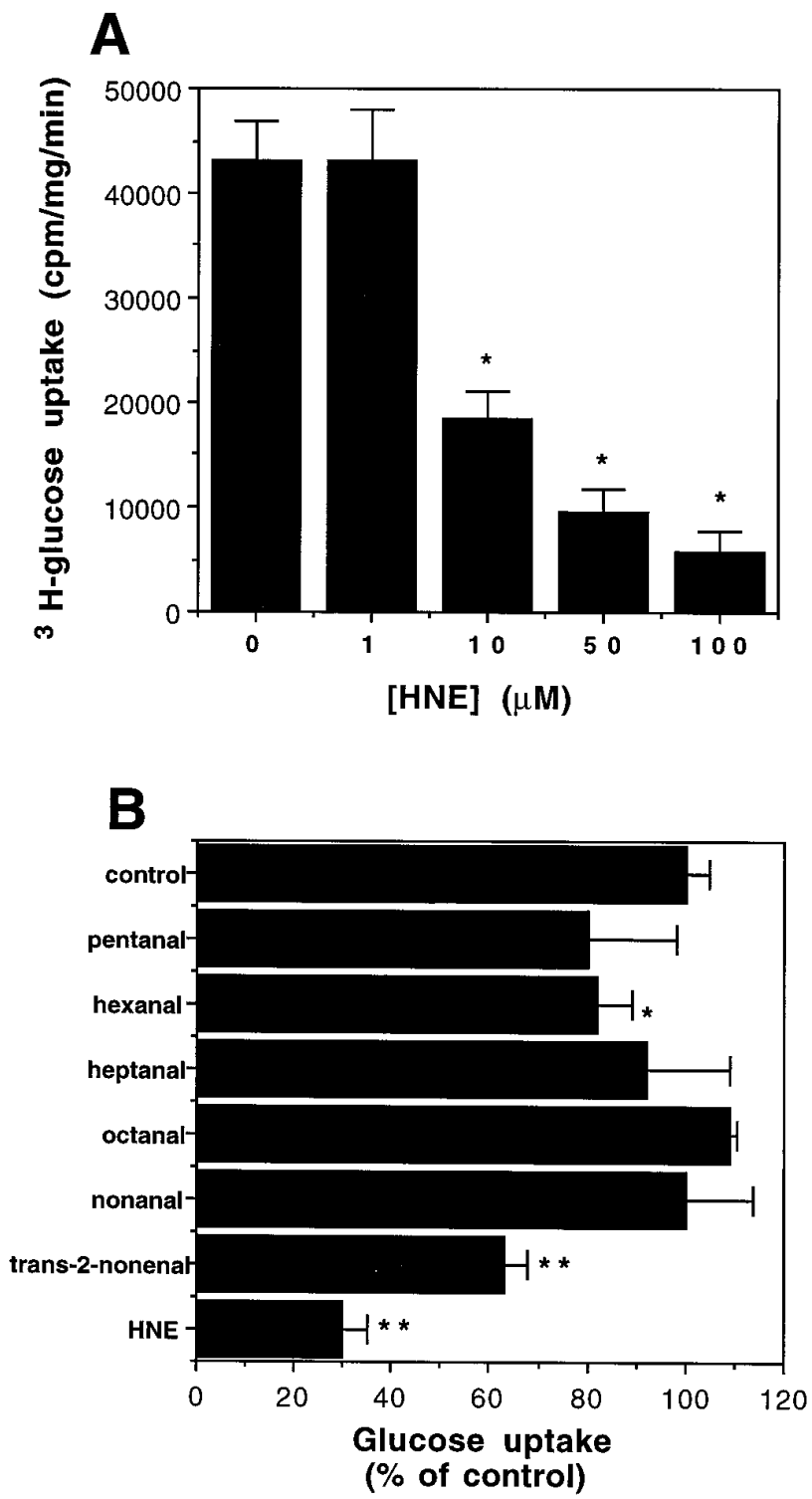

Figure 4. HNE impairs glucose uptake in hippocampal cell cultures. $A$, Cultures were exposed for $3 \mathrm{hr}$ to the indicated concentrations of HNE, and $\left[{ }^{3} \mathrm{H}\right]$-glucose uptake was quantified. Values represent the mean and $\mathrm{SD}$ of determinations made in five separate cultures. ${ }^{*} p<0.005 . B$, Other aldehydic products of lipid peroxidation have no effect on the rate of glucose uptake. Cortical cultures were treated with $10 \mu \mathrm{M} \mathrm{HNE}$ or $250 \mu \mathrm{M}$ of the indicated aldehydes for $3 \mathrm{hr}$, and $\left[{ }^{3} \mathrm{H}\right]$-glucose uptake was quantified. Values are the mean and SD of determinations made in six separate cultures. ${ }^{*} p<0.05,{ }^{* *} p<0.001$ compared to control cultures. ANOVA with Scheffe's post hoc analysis.

whether HNE would impair glucose transport. Exposure of cultures to increasing concentrations of $\mathrm{HNE}$ for $3 \mathrm{hr}$ resulted in a concentration-dependent inhibition of glucose transport (Fig. $4 A$ ). One micromolar HNE had no significant effect on glucose transport, whereas 10 and $100 \mu \mathrm{M}$ HNE reduced glucose transport by $70 \%$ and $90 \%$, respectively. Impairment of glucose transport occurred more rapidly in cells exposed to HNE than in cells exposed to $\mathrm{A} \beta$ such that a maximal decrease was observed within $3 \mathrm{hr}$ of exposure to HNE, whereas it took 6-12 hr to observe maximal decreases in cells exposed to $\mathrm{A} \beta 25-35$ (Figs. $1 \mathrm{~B}, 4 \mathrm{~A}$; and data not shown). The impairment of glucose transport activity was specific to HNE, because other aldehydic by-products of lipid peroxidation (pentanal, hexanal, heptanal, octanal, and nonanal) had little or no effect even at the very high concentration of 250 $\mu \mathrm{M}$ (Fig. $4 B)$. Trans-2-nonenal $(250 \mu \mathrm{M})$ did cause a significant decrease in glucose transport, although $10 \mu \mathrm{M}$ of this aldehyde did not impair glucose transport (data not shown).

HNE is known to conjugate to lysine, histidine, and cysteine residues of proteins, and this interaction can impair the functions of those proteins (Uchida and Stadtman, 1992; Uchida et al., 1993; Siems et al., 1996; Mark et al., 1997). In preliminary studies we found that, consistent with previous in situ hybridization and immunocytochemical studies in adult rodent brain and cerebellar cell cultures (Maher and Simpson, 1994a,b; Simpson et al., 1994a; Maher et al., 1996), GLUT3 is expressed at high levels in cultured hippocampal neurons (Figs. 5, 6). GLUT1 immunoreactivity was not detectable in Western blot analysis of protein from our hippocampal or cortical cultures (data not shown). GLUT3 immunoreactivity was not present in astrocytes (Fig. 5), consistent with GLUT2 mediating glucose uptake in astrocytes (Simpson et al., 1994a). To determine whether HNE can conjugate directly to GLUT3, and whether $A \beta$ can induce such conjugation, we used immunoprecipitation and Western blot analyses using antibodies to GLUT3 and HNE. Cultures were exposed for $4 \mathrm{hr}$ to vehicle, $10 \mu \mathrm{M} \mathrm{A} \beta 25-35$, or $10 \mu \mathrm{M}$ HNE. Cell proteins were then immunoprecipitated with a GLUT3 antibody and then Western-blotted using an anti-HNE antibody. A single HNE immunoreactive band at the molecular weight of GLUT3 (45 kDa) was observed in the cultures exposed to $\mathrm{HNE}$ and $\mathrm{A} \beta$ but not in control cultures (Fig. 6).

\section{DISCUSSION}

The present data demonstrate that $\mathrm{A} \beta$ can impair glucose uptake in cultured hippocampal and cortical neurons by a mechanism involving HNE, an aldehydic product of membrane lipid peroxidation. $\mathrm{A} \beta$ decreased the rate of glucose transport in a concentration-dependent manner; effective concentrations were in the range shown to be neurotoxic in the present study and previous studies (Yankner et al., 1990; Mattson et al., 1993b; Pike et al., 1993). The decrease in glucose transport after exposure to $\mathrm{A} \beta$ was relatively rapid, occurring within 1-2 hr of exposure, and preceded neurotoxicity, which did not become evident until after $6 \mathrm{hr}$ of exposure. This time frame of impairment of glucose transport is consistent with a post-translational effect on function of the transporter, rather than an effect on expression of the transport protein. Our Western blot analysis of GLUT3 protein after $\mathrm{A} \beta$ treatment showed no change in GLUT3 protein levels, even after $6 \mathrm{hr}$ of treatment (data not shown). $\mathrm{FeSO}_{4}$ and $\mathrm{HNE}$ also reduced glucose transport within $2 \mathrm{hr}$ of exposure, and the antioxidants $n$-propyl gallate and vitamin E blocked impairment of glucose transport by $\mathrm{A} \beta$, suggesting the involvement of oxyradical-mediated damage to the transporter. The observations that $\mathrm{A} \beta$ induced HNE production and conjugation to GLUT3, and HNE impaired glucose transport, further suggest a major role for lipid peroxidation in compromise of glucose transporter function. The concentrations of HNE produced in cultured hippocampal cells exposed to $\mathrm{A} \beta$ are in the range of 1-10 $\mu \mathrm{M}$ (Mark et al., 1997), concentrations that in the present study impaired glucose transport.

$\mathrm{A} \beta$-induced impairment of glucose transport preceded the decrease in cellular ATP levels, suggesting the possibility that the reduced glucose uptake was causally linked to ATP depletion. With the same hippocampal culture system used in the present study, we showed previously that cellular ATP levels decrease by 

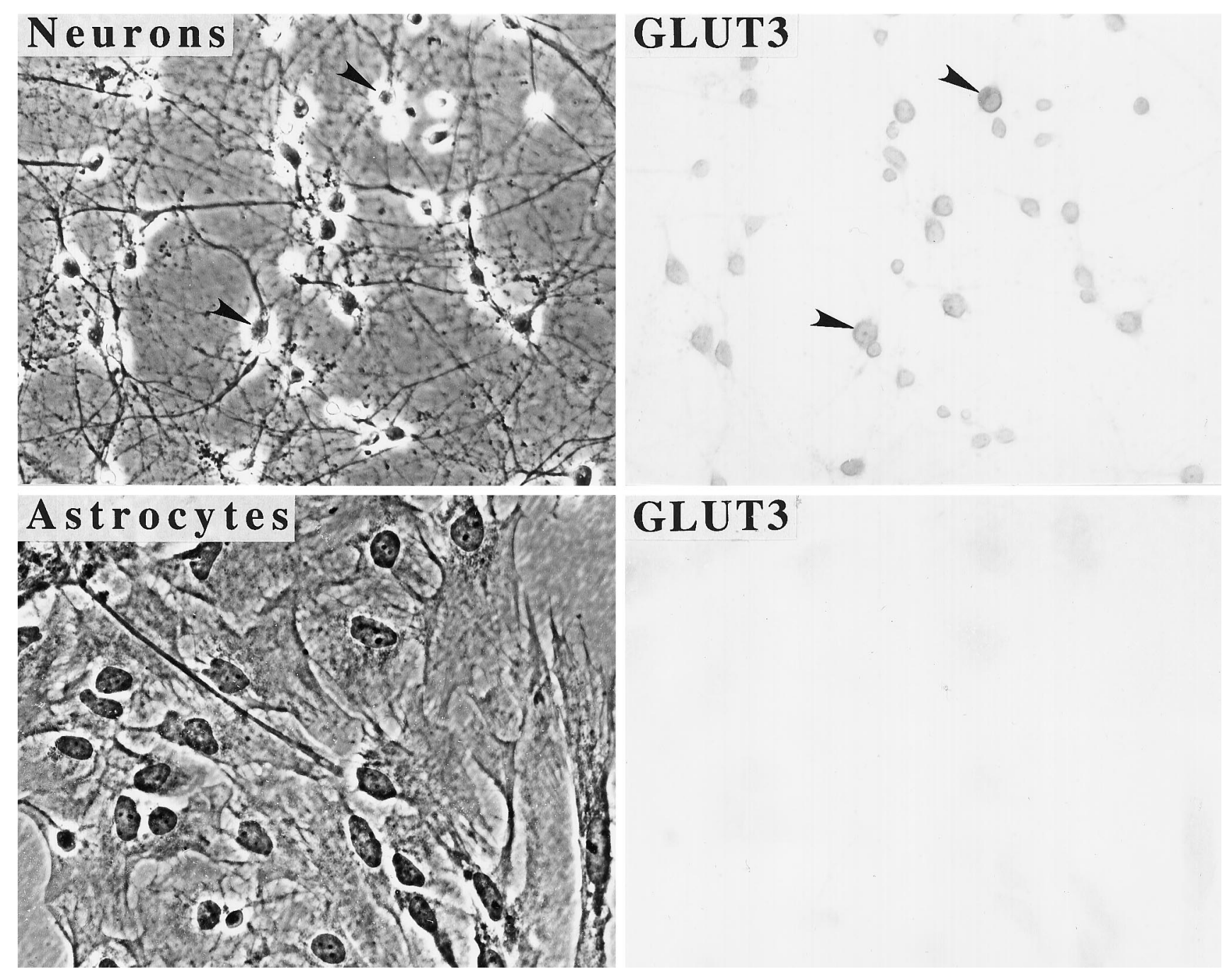

GLUT3

Figure 5. GLUT3 is expressed at high levels in cultured hippocampal neurons. Shown are phase-contrast (left) and bright-field (right) micrographs of cultured hippocampal neurons (top) and cortical astrocytes (bottom) immunostained with an antibody to GLUT3. Note that neurons exhibit considerable GLUT3 immunoreactivity, whereas astrocytes do not. Arrowheads point to neuron cell bodies (top panels).

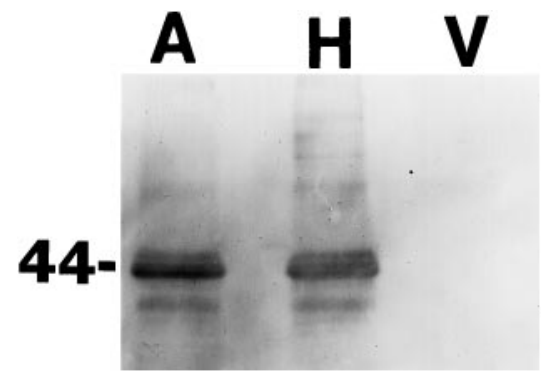

Figure 6. $\mathrm{A} \beta$ induces HNE production and conjugation to the glucose transporter. Neocortical cultures were exposed for $4 \mathrm{hr}$ to $10 \mu \mathrm{M}$ A $\beta 25-35$ $(A), 10 \mu \mathrm{M}$ HNE $(H)$, or vehicle $(V)$. Solubilized total cell protein was immunoprecipitated with an antibody against the glucose transporter, and the antibody-bound proteins were separated by SDS-PAGE, transferred to nitrocellulose, and immunoreacted with an HNE antibody (see Materials and Methods).

$>30 \%$ within $1 \mathrm{hr}$ after glucose withdrawal (Mattson et al., 1993c). In the present study we showed that phloretin, a specific inhibitor of glucose transport (Yokota et al., 1983), caused a decrease in cellular ATP levels. Thus, inhibition of glucose trans- port is sufficient to account for the suppressive effects of $\mathrm{A} \beta$ and HNE on cellular ATP levels. Previous studies have shown that A $\beta$ impairs mitochondrial activity, as indicated by a decreased ability of neurons and synaptosomes exposed to $\mathrm{A} \beta$ to reduce the compound 3-(4:5-dimethylthiazol-2-yl)-2:5-diphenyltetrazolium bromide (MTT) (Shearman et al., 1994; Keller et al., 1997). Although not established in the present study, it is conceivable that reduced glucose availability to mitochondria may contribute to the observed decrease in MTT reduction. Metabolic impairment is known to increase neuronal vulnerability to excitotoxicity (Novelli et al., 1988; Bowling and Beal, 1995). Neuronal death induced by glucose deprivation involves activation of NMDA receptors and calcium overload (Cheng and Mattson, 1992a). Impairment of glucose transport may therefore provide an explanation for the fact that exposure of cultured neurons to $\mathrm{A} \beta$ increases their vulnerability to excitotoxicity (Koh et al., 1990; Mattson et al., 1992). Zhang et al. (1996) recently reported that $A \beta 1-40$ induced a relatively slow decrease in ATP levels in cultured primary neurons that did not occur until after $6 \mathrm{hr}$ of exposure; the rate of glucose utilization fell only slightly during the first $18 \mathrm{hr}$ of exposure to $\mathrm{A} \beta 1-40 .{ }^{3} \mathrm{H}$-glucose transport was not examined in the latter study. In the present study we found that the time course 
of impairment of glucose transport in neurons exposed to $A \beta 1-40$ was slower than in neurons exposed to $A \beta 25-35$, and in general we find that $A \beta 25-35$ is more potent than $A \beta 1-40$ in various cytotoxicity assays (e.g., Mark et al., 1995a). Differences in time course and concentration-dependence of the neurotoxic actions of $\mathrm{A} \beta$, however, have previously been related to lot-to-lot variability in the aggregation kinetics of different batches of $\mathrm{A} \beta$ (May et al., 1992), which may explain the quantitative differences between our data and those of Zhang et al. (1996).

Taken together with previous findings (Behl et al., 1994; Butterfield et al., 1994; Mark et al., 1995a, 1997; Goodman et al., 1996; Harris et al., 1996), the present data suggest a scenario in which $A \beta$ induces membrane lipid peroxidation and generation of HNE. HNE then binds to membrane proteins involved in transport of ions $\left(\mathrm{Na}^{+} / \mathrm{K}^{+}\right.$-ATPase and $\mathrm{Ca}^{2+}$-ATPase) (Mark et al., 1995a, 1997), glutamate (Keller et al., 1997), and glucose and impairs their function. Impairment of the $\mathrm{Na}^{+} / \mathrm{K}^{+}$-ATPase results in membrane depolarization and promotes $\mathrm{Ca}^{2+}$ influx through NMDA receptors and voltage-dependent channels. Impairment of glutamate transport results in excessive accumulation of extracellular glutamate, with consequent overstimulation of glutamate receptors. Impairment of glucose transport results in ATP depletion, compromise of ion-motive ATPase function, and increased vulnerability to excitotoxic and oxidative insults. Previous studies have shown that A $\beta$ (Koh et al., 1990; Mattson et al., 1992), HNE (Mark et al., 1997), and ouabain (Brines et al., 1995; Calabresi et al., 1995) increase neuronal vulnerability to excitotoxicity. A $\beta$ (Loo et al., 1993), HNE (Kruman et al., 1996), and ouabain (Mark et al., 1995a) each also induce apoptosis in cultured neurons, and such cell death can be suppressed by agents that suppress lipid peroxidation (Behl et al., 1994; Goodman and Mattson, 1994; Goodman et al., 1996), detoxify HNE (Mark et al., 1997), or stabilize ion homeostasis (Mark et al., 1995a,b). These data suggest pivotal roles for lipid peroxidation, HNE production, and disruption of ion homeostasis in neuronal apoptosis induced by $\mathrm{A} \beta$.

By inducing ATP depletion, A $\beta$ might also alter protein phosphorylation reactions mediated by various kinases that could contribute to certain aspects of the neurodegenerative process. For example, both $\mathrm{A} \beta$ and metabolic/excitotoxic insults have been shown to alter the phosphorylation of various cytoskeletal proteins, including the microtubule-associated protein tau, a key component of neurofibrillary tangles in AD (Ko et al., 1990; Mattson, 1990; Cheng and Mattson, 1992b; Busciglio et al., 1995; Smith-Swintosky et al., 1996).

Although studies of neurons in dissociated cell cultures cannot provide conclusive evidence for mechanisms operative in AD patients, the present data suggest that lipid peroxidation induced by $\mathrm{A} \beta$ may underlie the well documented impairment of glucose transport in $\mathrm{AD}$ brain. Evidence linking $\mathrm{A} \beta$ to increased oxidative stress in AD brain is accumulating and includes data that show the following: increased levels of lipid peroxidation and protein oxidation in brain regions where fibrillar $\mathrm{A} \beta$ accumulates (Smith et al., 1991; Lovell et al., 1995); the presence of advanced glycation end-products, markers of oxidative stress, in neuritic plaques (Smith et al., 1994; Vitek et al., 1994); and genetic and biochemical data suggesting impaired mitochondrial function in AD brain cells (for reviews, see Luft, 1994; Benzi and Moretti, 1995). Associations between $\mathrm{A} \beta$ deposition and impaired glucose transport in $\mathrm{AD}$ have not been established; however, brain imaging data indicate that deficits in glucose uptake are greatest in brain regions such as the temporal (entorhinal cortex and hippocampus) and parietal cortex (Piert et al., 1996), where there is the greatest amyloid burden (Cummings and Cotman, 1995). Studies of the inter-relationships of $\mathrm{A} \beta$ deposition, oxidative stress, glucose transport, and neuron degeneration in transgenic mice expressing human $\beta$ APP mutations (Games et al., 1995; Hsaio et al., 1996) may prove useful in establishing sequences of events and cause-effect relationships in the neurodegenerative process in $\mathrm{AD}$.

\section{REFERENCES}

Barger SW, Mattson MP (1996) Induction of neuroprotective $\kappa$ Bdependent transcription by secreted forms of the Alzheimer's $\beta$-amyloid precursor. Mol Brain Res 40:116-126.

Behl C, Davis J, Lesley R, Schubert D (1994) Hydrogen peroxide mediates amyloid $\beta$ protein toxicity. Cell 77:817-827.

Benzi G, Moretti A (1995) Age- and peroxidative stress-related modifications of the cerebral enzymatic activities linked to mitochondria and the glutathione system. Free Radic Biol Med 19:77-101.

Blass JP (1993) Metabolic alterations common to neural and non-neural cells in Alzheimer's disease. Hippocampus 3:45-54.

Bowling AC, Beal MF (1995) Bioenergetic and oxidative stress in neurodegenerative diseases. Life Sci 56:1151-1171.

Brines ML, Dare AO, de Lanerolle NC (1995) The cardiac glycoside ouabain potentiates excitotoxic injury of adult neurons in rat hippocampus. Neurosci Lett 191:145-148.

Busciglio J, Lorenzo A, Yeh J, Yankner BA (1995) $\beta$-amyloid fibrils induce tau phosphorylation and loss of microtubule binding. Neuron 14:879-888.

Butterfield DA, Hensley K, Harris M, Mattson MP, Carney J (1994) $\beta$-amyloid peptide free radical fragments initiate synaptosomal lipoperoxidation in a sequence-specific fashion: implications to Alzheimer's disease. Biochem Biophys Res Commun 200:710-715.

Cai X, Golde T, Younkin S (1993) Release of excess amyloid $\beta$ protein from a mutant amyloid $\beta$ protein precursor. Science 259:514-516.

Calabresi P, De Murtas M, Pisani A, Stefani A, Sancesario G, Mercuri NB, Bernardi G (1995) Vulnerability of medium spiny striatal neurons to glutamate: role of $\mathrm{Na}^{+} / \mathrm{K}^{+}$ATPase. Eur J Neurosci 7:1674-1683.

Cheng B, Mattson MP (1992a) IGF-I and IGF-II protect cultured hippocampal and septal neurons against calcium-mediated hypoglycemic damage. J Neurosci 12:1558-1566.

Cheng B, Mattson MP (1992b) Glucose deprivation elicits neurofibrillary tangle-like antigenic changes in hippocampal neurons: prevention by NGF and bFGF. Exp Neurol 117:114-123.

Citron M, Oltersdorf T, Haass C, McConlogue L, Hung A, Seubert P, Vigo-Pelfrey C, Lieberburg I, Selkoe D (1992) Mutation of the betaamyloid precursor protein in familial Alzheimer's disease increases beta-protein production. Nature 360:672-674.

Cummings BJ, Cotman CW (1995) Image analysis of $\beta$-amyloid load in Alzheimer's disease and relation to dementia severity. Lancet 346:1524-1528.

Esterbauer H, Schaur RJ, Zollner H (1991) Chemistry and biochemistry of 4-hydroxynonenal, malonaldehyde and related aldehydes. Free Radic Biol Med 11:81-128.

Games D, Adams D, Alessandrini R, Barbour R, Berthelette P, Blackwell C, Carr T, Clemens J, Donaldson T, Gillespie F, Guido T, Hagoplan S, Johnson-Wood K, Khan K, Lee M, Lelbowitz E, McConlogue S, Montoya-Zavala M, Mucke L, Paganini L, Penniman E, Power M, Schenk D, Seubert P, Snyder B, Soriano F, Tan H, Vitale J, Wadsworth S, Wolozin B, Zhao J (1995) Alzheimer-type neuropathology in transgenic mice overexpressing V717F $\beta$-amyloid precursor protein. Nature 373:523-527.

Goodman Y, Mattson MP (1994) Secreted forms of $\beta$-amyloid precursor protein protect hippocampal neurons against amyloid $\beta$-peptideinduced oxidative injury. Exp Neurol 128:1-12.

Goodman Y, Bruce AJ, Cheng B, Mattson MP (1996) Estrogens attenuate and corticosterone exacerbates excitotoxicity, oxidative injury and amyloid $\beta$-peptide toxicity in hippocampal neurons. J Neurochem 66:1836-1844.

Greenamyre JT, Young AB (1989) Excitatory amino acids and Alzheimer's disease. Neurobiol Aging 10:593-602.

Harr SD, Simonian NA, Hyman BT (1995) Functional alterations in Alzheimer's disease: decreased glucose transporter 3 immunoreactivity in the perforant pathway terminal zone. J Neuropathol Exp Neurol $54: 38-41$.

Harris ME, Wang Y, Pedigo Jr NW, Hensley K, Butterfield DA, Carney JM (1996) Amyloid beta peptide (25-35) inhibits $\mathrm{Na}^{+}$-dependent glu- 
tamate uptake in rat hippocampal astrocyte cultures. J Neurochem 67:277-286

Horner HC, Packan DR, Sapolsky RM (1990) Glucocorticoids inhibit glucose transport in cultured hippocampal neurons and glia. Neuroendocrinology 52:57-64.

Hoyer S, Oesterreich K, Wagner O (1988) Glucose metabolism as the site of the primary abnormality in early-onset dementia of Alzheimer type? J Neurol 235:143-148.

Hsaio K, Chapman P, Nilsen S, Eckman C, Harigaya Y, Younkin S, Yang F, Cole G (1996) Correlative memory deficits, Ab elevation, and amyloid plaques in transgenic mice. Science 274:99-103.

Jagust WJ, Seab JP, Huesman RH, Valk PE, Mathis CA, Reed BR, Coxson PG, Budinger TF (1991) Diminished glucose transport in Alzheimer's disease: dynamic PET studies. J Cereb Blood Flow Metab 11:323-330.

Kalaria RN, Harik SI (1989) Reduced glucose transporter at the bloodbrain barrier and in cerebral cortex in Alzheimer's disease. J Neurochem 53:1083-1088.

Keller JN, Mark RJ, Bruce AJ, Blanc EM, Rothstein JD, Uchida K, Mattson MP (1997) 4-hydroxynonenal, an aldehydic product of membrane lipid peroxidation, impairs glutamate transport and mitochondrial function in synaptosomes. Neuroscience, in press.

Kelly J, Furukawa K, Barger SW, Mark RJ, Rengen MR, Roth G, Mattson MP (1996) Amyloid $\beta$-peptide disrupts carbachol-induced muscarinic cholinergic signal transduction in cortical neurons. Proc Natl Acad Sci USA 93:6753-6758.

Kennedy AM, Frackowiak RS, Newman SK, Bloomfield PM, Seaward J, Roques P, Lewington G, Cunningham VJ, Rossor MN (1995) Deficits in cerebral glucose metabolism demonstrated by positron emission tomography in individuals at risk of familial Alzheimer's disease. Neurosci Lett 186:17-20.

Ko LW, Sheu KF, Young O, Thaler H, Blass JP (1990) Expression in cultured human neuroblastoma cells of epitopes associated with affected neurons in Alzheimer's disease. Am J Pathol 136:867-879.

Koh J-Y, Yang LL, Cotman CW (1990) $\beta$-amyloid protein increases the vulnerability of cultured cortical neurons to excitotoxic damage. Brain Res 533:315-320.

Kruman I, Guo Q, Bruce AJ, Bredesen DE, Mattson MP 1996 Hydroxynonenal may mediate apoptotic neuronal death induced by trophic factor withdrawal and oxidative insults. Soc Neurosci Abstr 22:1481.

Loo DT, Copani A, Pike CJ, Whittemore ER, Walencewicz AJ, Cotman CW (1993) Apoptosis is induced by beta-amyloid in cultured central nervous system neurons. Proc Natl Acad Sci USA 90:7951-7955.

Lovell MA, Ehmann WD, Butler SM, Markesbery WR (1995) Elevated thiobarbituric acid-reactive substances and antioxidant enzyme activity in the brain in Alzheimer's disease. Neurology 45:1594-1601.

Luft R (1994) The development of mitochondrial medicine. Proc Natl Acad Sci USA 91:8731-8738.

Maher F, Simpson IA (1994a) The GLUT3 glucose transporter is the predominant isoform in primary cultured neurons: assessment by biosynthetic and photoaffinity labelling. Biochem J 301:379-384.

Maher F, Simpson IA (1994b) Modulation of expression of glucose transporters GLUT3 and GLUT1 by potassium and $N$-methyl-Daspartate in cultured cerebellar granule neurons. Mol Cell Neurosci 5:369-375.

Maher F, Davies-Hill TM, Simpson IA (1996) Substrate specificity and kinetic parameters of GLUT3 in rat cerebellar granule neurons. Biochem J 315:827-831.

Mark RJ, Hensley K, Butterfield DA, Mattson MP (1995a) Amyloid $\beta$-peptide impairs ion-motive ATPase activities: evidence for a role in loss of neuronal $\mathrm{Ca}^{2+}$ homeostasis and cell death. $\mathrm{J}$ Neurosci 15:6239-6249.

Mark RJ, Ashford JW, Mattson MP (1995b) Anticonvulsants attenuate amyloid $\beta$-peptide neurotoxicity and promote maintenance of calcium homeostasis. Neurobiol Aging 16:187-198.

Mark RJ, Lovell MA, Markesbery WR, Uchida K, Mattson MP (1997) A role for 4-hydroxynonenal in disruption of ion homeostasis and neuronal death induced by amyloid $\beta$-peptide. J Neurochem, in press.

Mattson MP (1990) Antigenic changes similar to those seen in neurofibrillary tangles are elicited by glutamate and calcium influx in cultured hippocampal neurons. Neuron 4:105-117.

Mattson MP (1995) Untangling the pathophysiochemistry of $\beta$-amyloid. Nat Struct Biol 2:926-928.

Mattson MP, Cheng B, Davis D, Bryant K, Lieberburg I, Rydel RE (1992) $\beta$-amyloid peptides destabilize calcium homeostasis and render human cortical neurons vulnerable to excitotoxicity. J Neurosci 12:376-389.

Mattson MP, Barger SW, Cheng B, Lieberburg I, Smith-Swintosky VL, Rydel RE (1993a) $\beta$-amyloid precursor protein metabolites and loss of neuronal calcium homeostasis in Alzheimer's disease. Trends Neurosci 16:409-415.

Mattson MP, Tomaselli K, Rydel RE (1993b) Calcium-destabilizing and neurodegenerative effects of aggregated $\beta$-amyloid peptide are attenuated by basic FGF. Brain Res 621:35-49.

Mattson MP, Zhang Y, Bose S (1993c) Growth factors prevent mitochondrial dysfunction, loss of calcium homeostasis and cell injury, but not ATP depletion in hippocampal neurons deprived of glucose. Exp Neurol 121:1-13.

Mattson MP, Barger SW, Begley JG, Mark RJ (1995) Calcium, free radicals, and excitotoxic neuronal death in primary cell culture. Methods Cell Biol 46:187-216.

May PC, Gitter BD, Waters DC, Simmons LK, Becker GW, Small JS, Robison PM (1992) $\beta$-Amyloid in vitro toxicity: lot-to-lot variability. Neurobiol Aging 13:605-607.

Montine TJ, Amarnath V, Martin ME, Strittmatter WJ, Graham DG (1996) E-4-hydroxy-2-nonenal is cytotoxic and cross-links cytoskeletal proteins in P19 neuroglial cultures. Am J Pathol 148:89-93.

Mullan M, Crawford F (1993) Genetic and molecular advances in Alzheimer's disease. Trends Neurosci 16:398-403.

Novelli A, Reilly JA, Lyska PC, Henneberry RC (1988) Glutamate becomes neurotoxic via the $N$-methyl-D-aspartate receptor when intracellular energy levels are reduced. Brain Res 451:205-212.

Pettegrew JW, Panchalingam K, Klunk WE, McClure RJ, Muenz LR (1994) Alterations of cerebral metabolism in probable Alzheimer's disease: a preliminary study. Neurobiol Aging 15:117-132.

Piert M, Koeppe RA, Giordani B, Berent S, Kuhl DE (1996) Diminished glucose transport and phosphorylation in Alzheimer's disease determined by dynamic FDG-PET. J Nucl Med 37:201-208.

Pike C, Burdick D, Walencewicz A, Glabe C, Cotman C (1993) Neurodegeneration induced by $\beta$-amyloid peptides in vitro: the role of peptide assembly state. J Neurosci 13:1676-1686.

Reiman EM, Caselli RJ, Yun LS, Chen K, Bandy D, Minoshima S, Thibodeau SN, Osborne D (1996) Preclinical evidence of Alzheimer's disease in persons homozygous for the epsilon 4 allele for apolipoprotein E. New Engl J Med 334:752-758.

Selkoe DJ (1993) The molecular pathology of Alzheimer's disease. Neuron 6:487-498.

Shearman MS, Ragan CI, Iversen LL (1994) Inhibition of PC12 cell redox activity is a specific, early indicator of the mechanism of $\beta$-amyloid-mediated cell death. Proc Natl Acad Sci USA 91:1470-1474.

Siems WG, Hapner SJ, van Kuijk FJGM (1996) 4-hydroxynonenal inhibits $\mathrm{Na}^{+}-\mathrm{K}^{+}$-ATPase. Free Radic Biol Med 20:215-223.

Simpson IA, Vannucci SJ, Maher F (1994a) Glucose transporters in mammalian brain. Biochem Soc Trans 22:671-675.

Simpson IA, Chundu KR, Davies-Hill T, Honer WG, Davies P (1994b) Decreased concentrations of GLUT1 and GLUT3 glucose transporters in the brains of patients with Alzheimer's disease. Ann Neurol 35:546-551.

Sims NR (1990) Altered glucose metabolism in Alzheimer's disease. Ann Neurol 27:691-693.

Smith CD, Carney JM, Starke-Reed PE, Oliver CN, Stadtman ER, Floyd RA, Markesbery WR (1991) Excess brain protein oxidation and enzyme dysfunction in normal aging and in Alzheimer disease. Proc Natl Acad Sci USA 88:10540-10543.

Smith MA, Taneda S, Richey PL, Miyata S, Yan SD, Stern D, Sayre LM, Monnier VM, Perry G (1994) Advanced Maillard reaction end products are associated with Alzheimer disease pathology. Proc Natl Acad Sci USA 91:5710-5714.

Smith MA, Sayre LM, Monnier VM, Perry G (1995) Radical ageing in Alzheimer's disease. Trends Neurosci 18:172-176.

Smith-Swintosky VL, Pettigrew LC, Sapolsky RM, Phares C, Craddock SD, Brooke SM, Mattson MP (1996) Metyrapone, an inhibitor of glucocorticoid production, reduces brain injury induced by focal and global ischemia and seizures. J Cereb Blood Flow Metab 16:585-598.

Suzuki N, Cheung T, Cai X, Odaka A, Otovos L, Eckman L, Golde T, Younkin S (1994) An increased percentage of long amyloid $\beta$ protein secreted by familial amyloid $\beta$ protein precursor $\left(\beta A P_{717}\right)$ mutants. Science 264:1336-1340.

Uchida K, Stadtman ER (1992) Modification of histidine residues in 
proteins by reaction with 4-hydroxynonenal. Proc Natl Acad Sci USA 89:4544-4548.

Uchida K, Szweda LI, Chae HZ, Stadtman ER (1993) Immunochemical detection of 4-hydroxynonenal protein adducts in oxidized hepatocytes. Proc Natl Acad Sci USA 90:8742-8746.

Vitek MP, Bhattacharya K, Glendening JM, Stopa E, Vlassara H, Bucala R, Manogue K, Cerami A (1994) Advanced glycation end products contribute to amyloidosis in Alzheimer disease. Proc Natl Acad Sci USA 91:4766-4770.

Yankner BA (1996) Mechanisms of neuronal degeneration in Alzheimer's disease. Neuron 16:921-932.

Yankner BA, Duffy LK, Kirschner DA (1990) Neurotrophic and neuro- toxic effects of amyloid beta protein: reversal by tachykinin neuropeptides. Science 250:279-282.

Yokota K, Nishi Y, Takesue Y (1983) Effect of phloretin on $\mathrm{Na}^{+}$dependent $\mathrm{D}$-glucose uptake by intestinal brush border membrane vesicles. Biochem Pharmacol 32:3453-3457.

Zhang Y, Tatsuno T, Carney J, Mattson MP (1993) Basic FGF, NGF, and IGFs protect hippocampal neurons against iron-induced degeneration. J Cereb Blood Flow Metab 13:378-388.

Zhang Z, Rydel RE, Drzewiecki GJ, Fuson K, Wright S, Wogulis M, Audia JE, May PC, Hyslop PA (1996) Amyloid $\beta$-mediated oxidative and metabolic stress in rat cortical neurons: no direct evidence for a role for $\mathrm{H}_{2} \mathrm{O}_{2}$ generation. J Neurochem 67:1595-1606. 